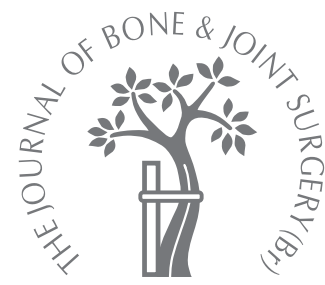

\title{
Impaction grafting of the acetabulum with a mixture of frozen, ground irradiated bone graft and porous synthetic bone substitute (Apapore 60)
}

\section{McNamara, S. Deshpande, M. Porteous}

From Department of Orthopaedics, West Suffolk Hospital, Bury St Edmunds, England
I. McNamara, MA(Cantab) $\mathrm{BM}, \mathrm{BCh}$ (Oxon), MRCP, MRCS, Specialist Registrar West Suffolk Hospital, NHS Trust, Hardwick Lane, Bury St Edmunds, Suffolk IP33 2QZ, UK. and

The Orthopaedic Research Unit Addenbrooke's Hospital, Hills Road, Cambridge CB2 0QQ, UK.

In. Seshpande, MS(Orth), MRCS(Edin), FCPS, Consultant Orthopaedic Surgeon

M. Porteous, MBBS FRCS(Orth), Consultant Trauma and Orthopaedic Surgeon West Suffolk Hospital NHS Trust, Hardwick Lane, Bury St Edmunds, Suffolk IP33 2OZ, UK.

Correspondence should be sent to Mr I. McNamara; e-mail: imcnamara@doctors.org.uk

(C)2010 British Editorial Society of Bone and Joint Surgery doi:10.1302/0301-620X.92B5. $23044 \$ 2.00$

$J$ Bone Joint Surg $[\mathrm{Br}]$ 2010;92-B:617-23.

Received 6 July 2009; Accepted after revision 15 January 2010

The clinical and radiological results of 50 consecutive acetabular reconstructions in 48 patients using impaction grafting have been retrospectively reviewed. A 1:1 mixture of frozen, ground irradiated bone graft and Apapore 60, a synthetic bone graft substitute, was used in all cases. There were 13 complex primary and 37 revision procedures with a mean follow-up of five years (3.4 to 7.6). The clinical survival rate was $100 \%$, with improvements in the mean Harris Hip Scores for pain and function. Radiologically, 30 acetabular grafts showed evidence of incorporation, ten had radiolucent lines and two acetabular components migrated initially before stabilising.

Acetabular reconstruction in both primary and revision surgery using a 1:1 mixture of frozen, ground, irriadiated bone and Apapore 60 appears to be a reliable method of managing acetabular defects. Longer follow-up will be required to establish whether this technique is as effective as using fresh-frozen allograft.

The management of loss of acetabular bone stock at revision total hip replacement (THR) is a major challenge. Impaction grafting using fresh-frozen morsellised allograft has been shown to be effective in long-term studies, but carries with it problems of cost, supply and potential infection. ${ }^{1-5}$ There is increasing evidence for the use of frozen, irradiated allograft bone in acetabular revision with all but one study having less than five years of follow-up. ${ }^{6-10}$ Problems associated with the biomechanical variability of donated bone remain, due to the mode of its preparation and its biological variability. ${ }^{11-19}$

One method of addressing these concerns is augmentation or replacement with synthetic bone graft substitutes. These have advantageous biomechanical properties in terms of their stiffness and the stability which they confer. ${ }^{20}$ Although they appear to be useful in animal models, no long-term clinical follow-up has been performed. ${ }^{20-26}$

The synthetic bone substitute used in this study was Apapore 60 (ApaTech Ltd, Elstree, United Kingdom), a phase-pure hydroxyapatite (HA) with $60 \%$ porosity. It has both a micro- $(<20 \mu \mathrm{m})$ and a macro- $(>50 \mu \mathrm{m})$ porosity. The combination of the pure-phase $\mathrm{HA}$ and this porous structure may improve osteoconductivity and hence encourage bone ingrowth and remodelling. ${ }^{27-31}$
We have evaluated the clinical and radiological results of using a mixture of ground, frozen, irradiated bone graft and Apapore 60 in patients undergoing acetabular impaction grafting.

\section{Patients and Methods}

We have used acetabular impaction grafting for revision and complex primary acetabular reconstruction since the mid-1990s. Before January 2002 all cases which had associated loss of acetabular bone had been managed with impaction grafting using only fresh-frozen morsellised bone graft. In January 2002, owing to difficulties in supply of the bone from the regional bone bank, a change in practice was instituted using a 1:1 mixture of frozen, ground irradiated bone graft and Apapore 60.

A total of five consultant surgeons performed the reconstructions, with the majority (47 of 53) being performed by the senior author (MP). All the bone graft was obtained from the National Blood and Tissue Services and had undergone irradiation using $25 \mathrm{kGy}$, and was packaged frozen and ready ground. The particles of bone provided were not graded, but we estimated the size as $1 \mathrm{~mm}$ to $3 \mathrm{~mm}$ in diameter. The particle size of the Apapore 60 was at $5 \mathrm{~mm}$ to $10 \mathrm{~mm}$.

A total of 53 patients underwent acetabular reconstruction. One patient was excluded as 
Table I. Patient characteristics and pre- and post-operative surgical information for primary and revision acetabular surgery

\begin{tabular}{|c|c|c|}
\hline & Primary surgery & Revision surgery \\
\hline Number of patients & 13 & 35 \\
\hline Number of hips & 13 & 37 \\
\hline \multicolumn{3}{|l|}{ Gender } \\
\hline Male:Female & $4: 9$ & 19:16 \\
\hline Left:Right & $9: 4$ & 19:18 \\
\hline Mean BMI* kg/m² (range) & 25 (17 to 42$)$ & $27.5(22$ to 31$)$ \\
\hline Mean age in years (range) & 74 (48 to 88 ) & $75 \quad(59$ to 90$)$ \\
\hline \multicolumn{3}{|l|}{ Indications for surgery } \\
\hline Osteoarthritis & 13 & \\
\hline Aseptic loosening & & 31 \\
\hline Second-stage revision for infection & & 4 \\
\hline Erosion following hemiarthroplasty & & 2 \\
\hline Mean follow-up in months (range) & 63.6 (47.5 to 86.4 ) & $\begin{array}{l}56.9 \text { (41.0 to } \\
91.4)\end{array}$ \\
\hline \multicolumn{3}{|l|}{ Mean pre-operative $\mathrm{HHS}^{\dagger}$ (range) } \\
\hline Pain & $(0$ to 20$)$ & (0 to 44$)$ \\
\hline Function & $20 \quad(15$ to 31$)$ & (3 to 36$)$ \\
\hline \multicolumn{3}{|l|}{ Mean post-operative HHS (range) } \\
\hline Pain & 38 (20 to 44$)$ & (40 to 44$)$ \\
\hline Function & 32 (10 to 47$)$ & (16 to 47 ) \\
\hline
\end{tabular}

she had no pre-operative questionnaire, having presented with a peri-prosthetic fracture and then subsequently died before the one-year follow-up. A further four patients were excluded as they had died from unrelated causes during the first post-operative year. There were no other losses to follow-up. Two patients had bilateral surgery, and thus a total of 48 patients and 50 hips were available for analysis. The mean follow-up for all patients was 60.3 months (41.0 to $91.4 ; 95 \%$ confidence interval (CI) 56.5 to 64.1$)$. The patient's details are presented in Table I.

All patients assessed at the time of surgery as requiring impaction grafting of the acetabulum for bone loss were included. Pre-operative anteroposterior (AP) pelvic radiographs and the findings at the time of surgery were used to classify the acetabular defects, according to the system of the American Academy of Orthopaedic Surgeons (AAOS) Committee on the hip. ${ }^{32}$

All the data were collected prospectively on our hip arthroplasty database (Orthowave, ARIA Sarl, Lille, France). Surgical technique. A posterior approach to the hip was used in all cases. In the case of primary reconstruction the femoral head was resected and the acetabulum was reamed to remove all remaining cartilage before any segmental defects were closed.

In cases of revision surgery the old implants and debris were removed and multiple samples of interface tissue were sent for microbiological culture to exclude infection. In both primary and revision surgery, segmental defects were reconstructed using mesh and screws prior to grafting. Any remaining sclerotic areas were perforated with multiple $5 \mathrm{~mm}$ drill holes and the bone bed cleaned with saline pulsed lavage. The allograft chips had been stored at $-80^{\circ} \mathrm{C}$ and were thawed at room temperature. For preparation, a 1:1 mixture (by weight) of the frozen, ground irradiated bone graft and Apapore 60, was mixed with $20 \mathrm{ml}$ of the patients' blood. The resultant composite was impacted in layers, each comprising approximately $15 \mathrm{ml}$ of graft into the acetabular cavity using X-change acetabular impaction grafting instruments (Stryker Howmedica Osteonics, Limerick, Ireland).

The last trial prosthesis that was used was at least $2 \mathrm{~mm}$ larger than the proposed acetabular component in order to allow for an adequate cement mantle. Polymethylmethacrylate bone cement (Palacos R+G, Heraeus, Wehrheim, Germany) was inserted into the cavity and pressurised using the Exeter acetabular pressuriser (Stryker Howmedica Osteonics). After pressurisation, a polyethylene acetabular component of the surgeon's preference, with an inner diameter of $26 \mathrm{~mm}$, was inserted and held until the cement had polymerised.

Post-operative regime. The post-operative treatment was based on the findings at operation and the stability of the components. Most patients remained partially weightbearing for six weeks. 
Table II. Operative findings and surgical procedure, including use of implants, for primary and revision acetabular reconstruction

\begin{tabular}{|c|c|c|}
\hline & Primary surgery & Revision surgery \\
\hline \multicolumn{3}{|l|}{ Acetabular defect type (AAOS ${ }^{*}$ classification) $)^{30}$} \\
\hline 1 & 4 & 13 \\
\hline II & 4 & 11 \\
\hline III & 5 & 13 \\
\hline Volume of graft (units bone + Apapore 60 ) & $2(1$ to 4.5$)$ & $4(2$ to 10$)$ \\
\hline \multicolumn{3}{|l|}{ Implants used: } \\
\hline \multicolumn{3}{|l|}{ Acetabulum } \\
\hline Mesh reconstruction & 9 & 22 \\
\hline Ring reconstruction & 1 & 3 \\
\hline Corin & 7 & 28 \\
\hline Ogee & 6 & 9 \\
\hline \multicolumn{3}{|l|}{ Femur } \\
\hline Exeter stem (Stryker) & 13 & 9 \\
\hline Revitan stem (Zimmer) & & 12 \\
\hline Cannulock (Orthodynamics) & & 4 \\
\hline Conelock (Biomet) & & 2 \\
\hline Dall cables (Stryker) & & 12 \\
\hline \multicolumn{3}{|l|}{ Post-operative radiologic findings } \\
\hline Graft incorporation & 10 & 20 \\
\hline Migration & 0 & 2 \\
\hline Radiolucency & 2 & 9 \\
\hline Failure & 0 & 1 \\
\hline Unable to assess & 1 & 1 \\
\hline
\end{tabular}

Follow-up. All patients had a plain AP pelvic and lateral plain radiograph prior to discharge. They were reviewed at six weeks, and then annually. All patients completed the pain and function parts of the Harris Hip Score (HHS) ${ }^{33}$ pre-operatively and annually thereafter.

Radiological follow-up. Serial AP and lateral radiographs were assessed to determine the extent and timing of the incorporation of the graft, the presence of radiolucent lines, localised resorption, or migration of the acetabular component. Trabecular remodelling was defined as a change in graft pattern, with the trabeculae running from the surface of the graft to the cement. ${ }^{34}$ Graft incorporation was defined as any change in the appearance of the post-operative radiograph short of fulfilling the criteria for remodelling. ${ }^{35}$ The progression of radiolucent lines with time was assessed. Zones of radiolucency were assessed according to the zones of DeLee and Charnley, ${ }^{36}$ with a radiolucent line measuring $2 \mathrm{~mm}$ in width considered to be a positive finding. Subsidence was determined on the AP radiograph by measuring the distance between the metallic wear marker in the polyethylene component and the 'teardrop' on the radiograph. Scaling of the measurements and correction for magnification on the radiographs was achieved by calibrating the measuring line on the software to the $26 \mathrm{~mm}$ femoral head. All radiological analyses were performed by three authors (IM, SD, MP) working together to reach a consensus.
Clinical failure was defined as revision or intention to revise. Radiological failure was defined by a progressive circumferential radiolucent line or migration of the acetabular component of $>5 \mathrm{~mm}$ in any direction relative to the interteardrop line, as seen on AP pelvic radiographs.

Survival analysis was performed using the life table method and CIs based on the effective number at risk using Rothman's equation. ${ }^{37,38}$ The effective number at risk is equal to the harmonic mean of the number at risk in each year, which is itself calculated as the number of patients at the beginning of each year, less the number of patients withdrawn. Hence a starting value of 55 hips was used to calculate the CI.

\section{Results}

No patients have required re-operation of either the femoral or the acetabular components. Their operative details are presented in Table II.

Primary acetabular reconstructions. Of the 13 primary reconstructions performed, the mean follow-up was for 63.6 months ( 47.5 to 86.4 ; $95 \%$ CI 55.9 to 71.3 ). No complications were recorded, and no patient had radiological or clinical failure. Two patients had radiolucent lines on the radiographs at one year post-operatively. The first had a $2.5 \mathrm{~mm}$ wide radiolucent line in zones II and III, the other an $0.5 \mathrm{~mm}$ line in zone I alone. In neither patient was there 


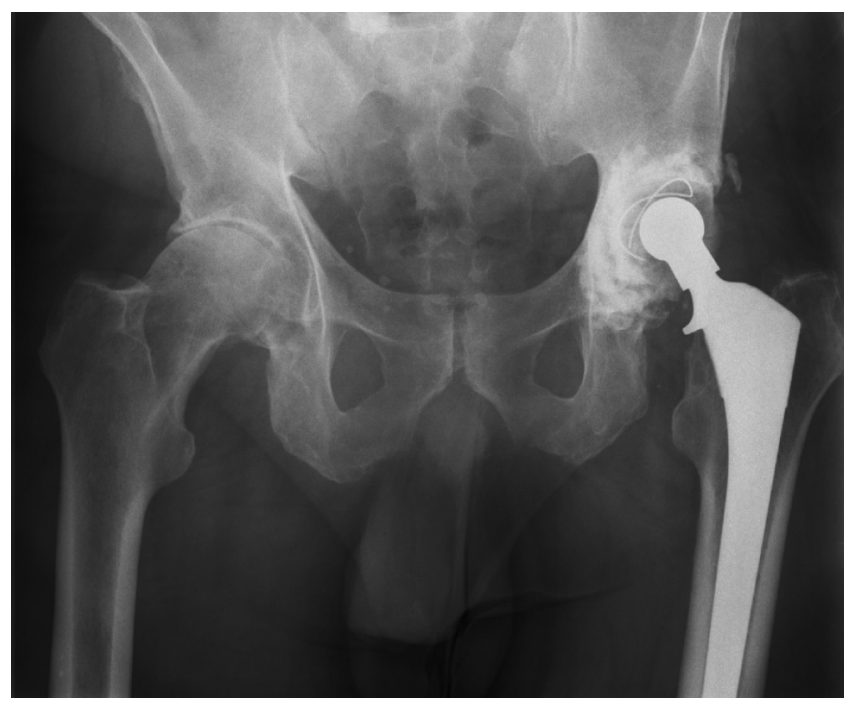

Fig. 1

Immediate post-operative radiograph of a reconstructed acetabulum with no subsidence or radiolucent lines.

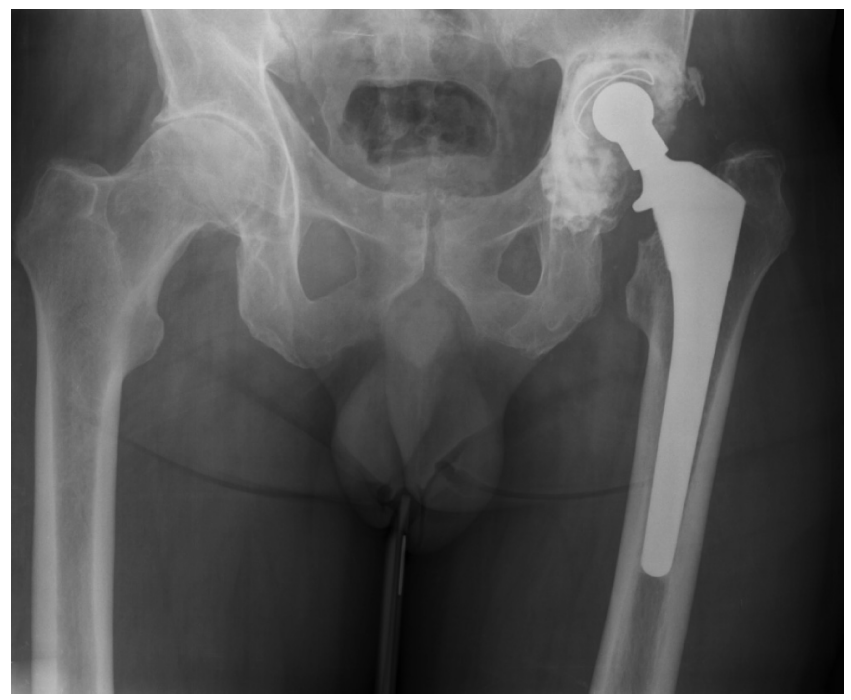

Fig. 2

A radiograph at 1-year follow-up of the same patient as in Figure 1, demonstrating subsidence of the acetabular component and the presence of radiolucent lines.

any progression of the radiolucent lines. The HHS for pain and function changed from 20 to 40 and from 19 to 35 for the first patient; and from 10 to 40 and 18 to 45 for the second patient from pre-operative to the first post-operative review at one year. There was evidence of graft incorporation in ten hips but the radiodense nature of the hydroxyapatite made the presence of trabeculae impossible to establish. One acetabulum could not be assessed because of overlying metalwork.

Revision acetabular reconstructions. In all, 37 acetabular revisions were performed, in eight of which the femoral component was not revised (Table II). The mean follow-up was for 56.9 months (41.0 to 91.4 ; $95 \%$ CI 52.6 to 61.2 ). Complications included one superficial infection treated with antibiotics, one deep infection managed by suppressive antibiotics, and one post-operative cardiac arrhythmia which was treated on the coronary care unit with no longterm sequelae.

One acetabular component migrated $8 \mathrm{~mm}$ medially. The patient was asymptomatic and all migration occurred within the first year. Subsequent annual radiographs demonstrated that the acetabular component had stabilised, but that a $2.5 \mathrm{~mm}$ radiolucent line had developed in zones 1 and 2 (Figs 1 and 2). The HHS for this patient changed from 20 to 44 and 27 to 30 for pain and function, respectively. One other acetabular component migrated by $3 \mathrm{~mm}$ during the first year and there was a $1.5 \mathrm{~mm}$ radiolucent line in zones 1 and 2 at the first year post-operative radiograph. Subsequent yearly radiographs have demonstrated no further migration or progression of the radiolucent lines. The HHS for the second patient changed from 0 to 10 and 27 to 24 for pain and function, respectively from preoperative to the post-operative review at one year. In total, seven other patients had radiolucent lines of $<2 \mathrm{~mm}$, three of which were in zone 1 , and three in zone 3 , and one patient had lines in zones 1 and 2 . No patients had lines in all three zones. Incorporation of the graft occurred in 20 patients (20 hips). It was not possible to assess this in one patient owing to the metalwork obscuring the graft.

Survival analysis is presented in Table III and Figure 3.

\section{Discussion}

Our results using a mixture of frozen, ground irradiated bone and a bone-graft substitute are comparable with published data at the same interval for frozen irradiated bone alone. ${ }^{6,7}$

A number of authors have published favourable results using morsellised fresh-frozen allograft for acetabular impaction grafting. ${ }^{39-44}$ However, there are concerns about the potential for transmission of disease from donor to recipient, and bacterial contamination, which can occur with fatal consequences. ${ }^{4,45-47}$ Anxiety about the transmission of infection has led to irradiation of the bone allograft as a means of sterilisation. The typical gamma irradiation dose for bone used in impaction grafting is $25 \mathrm{kGy}$, which effectively reduces the bacterial load but may not inactivate HIV. ${ }^{48}$

Although most clinical studies examining the use of morsellised bone in impaction grafting for the acetabulum have demonstrated similar results for irradiated and nonirradiated graft, ${ }^{7-9,49}$ concerns still exist that irradiation might affect the mechanical properties of the graft and its long-term biological incorporation. ${ }^{49-53}$

It has been demonstrated that a dose of $25 \mathrm{kGy}$ does not greatly affect the mechanical properties of the bone, but increasing the dose has a detrimental, non-linear effect on the strength of the bone. ${ }^{50,54-57}$ Irradiation has also been 
Table III. Life table for clinical acetabular survival. The $95 \%$ confidence intervals were calculated by Rothman's method $^{38}$

\begin{tabular}{|c|c|c|c|c|c|c|c|c|}
\hline $\begin{array}{l}\text { Years since } \\
\text { operation }\end{array}$ & $\begin{array}{l}\text { Number of } \\
\text { hips at start }\end{array}$ & $\begin{array}{l}\text { Clinical } \\
\text { failure }\end{array}$ & Withdrawn & $\begin{array}{l}\text { Lost to } \\
\text { follow-up }\end{array}$ & $\begin{array}{l}\text { Number at } \\
\text { risk }\end{array}$ & $\begin{array}{l}\text { Annual failure } \\
\text { rate }(\%)\end{array}$ & $\begin{array}{l}\text { Annual success } \\
\text { rate }(\%)\end{array}$ & $\begin{array}{l}\text { Survival } \\
\text { rate (\%) }\end{array}$ \\
\hline 0 to 1 & 55 & 0 & 5 & 0 & 52.5 & 0 & 100 & 100 \\
\hline 1 to 2 & 50 & 0 & 0 & 0 & 50 & 0 & 100 & 100 \\
\hline 2 to 3 & 50 & 0 & 0 & 0 & 50 & 0 & 100 & 100 \\
\hline 3 to 4 & 38 & 0 & 0 & 0 & 38 & 0 & 100 & 100 \\
\hline 4 to 5 & 24 & 0 & 0 & 0 & 24 & 0 & 100 & 100 \\
\hline 5 to 6 & 11 & 0 & 0 & 0 & 11 & 0 & 100 & 100 \\
\hline 6 to 7 & 5 & 0 & 0 & 0 & 5 & 0 & 100 & 100 \\
\hline 7 to 8 & 3 & 0 & 0 & 0 & 3 & 0 & 100 & 100 \\
\hline
\end{tabular}

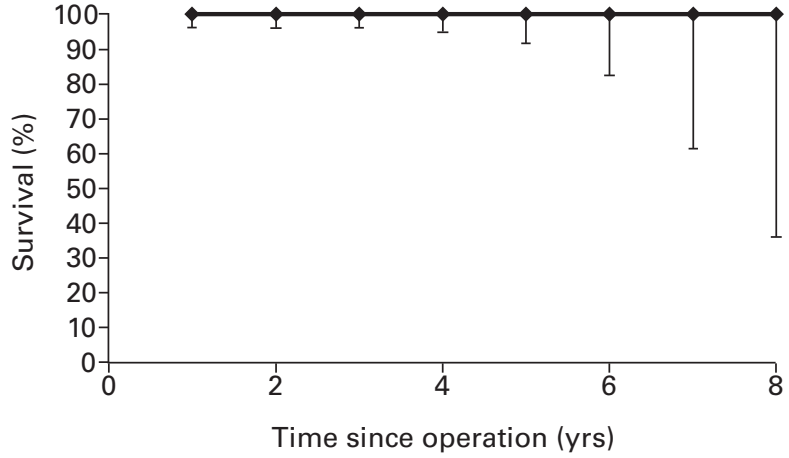

Fig. 3

Survival curve for acetabular components following impaction grafting. Error bars indicate $95 \%$ confidence intervals.

shown to impair the osteoconductive capacity of bone graft. This is thought to be due to oxidation of the lipids present in the marrow, rendering them cytotoxic to cultures of osteoblasts. ${ }^{52}$ Where irradiated allograft bone has been grafted into animal models, a dose-dependent effect of the radiation on a reduction in bone incorporation is generally observed. ${ }^{58-60}$

Washing morsellised graft has been shown to remove fat, an effect that is greater for smaller particle sizes ${ }^{61}$ and hence may diminish the problems related to oxidised lipids. This is supported by the observation that washed irradiated allograft implanted into a goat model has the same rate of incorporation as rinsed non-irradiated bone. ${ }^{62}$ Washing may therefore be as important in the preparation of irradiated graft as the dose of radiation itself. Of note, Mehendale et $\mathrm{al}^{49}$ described 50 patients who had undergone acetabular revision using unwashed irradiated bone, which had been irradiated with either $25 \mathrm{kGy}$ or $50 \mathrm{kGy}$ at a mean of 45 months. Good clinical results were described, but although $40 \%$ of patients had incorporation of bone, only $6 \%$ had evidence of remodelling. ${ }^{49}$ This is the only report in the literature commenting on washing irradiated graft, other than our own series, where the bone used had been washed and decontaminated by the central tissue bank using hydrogen peroxide and ethanol.
The optimum size of chip for impaction grafting is still not known. In their initial clinical series, Slooff et $\mathrm{l}^{63}$ used large, hand-prepared crouton-sized pieces of graft for impaction grafting in the acetabulum. Later, investigators using biomechanical studies demonstrated that large bone chips of between $8 \mathrm{~mm}$ and $10 \mathrm{~mm}$ confer greater stability to an acetabular model with a cemented component than a graft composed of smaller chips. ${ }^{64-67}$ Further experimental work has revealed the importance of particle size and distribution for early mechanical stability of the bone-graft bed. ${ }^{68}$

The ground irradiated bone chips used in this study were much smaller at $1 \mathrm{~mm}$ to $3 \mathrm{~mm}$ diameter than recommended by others. ${ }^{64-68}$ This might have been expected to result in a poor outcome, with marked migration of the acetabular component, but the addition of the larger, $5 \mathrm{~mm}$ to $10 \mathrm{~mm}$ particles of Apapore 60 produced a better-graded particle size than would have been achieved with the ground bone alone, especially as the impaction process fractures the Apapore 60 particles. It is likely that this resulted in improved distribution of particle size and enhanced stability of the graft bed.

In vitro studies have demonstrated improved implant stability in models using ceramic substitutes compared to morsellised bone graft alone, ${ }^{15,26,69-71}$ but there are fewer clinical studies. One such report used impacted HA particles into which an acetabular component was cemented, ${ }^{25}$ and another used impacted HA particles into which an uncemented acetabular component was introduced. ${ }^{72}$ Blom et $\mathrm{al}^{73}$ recently reported their results from acetabular reconstruction of contained defects using a biphasic $50 \%$ porosity bioceramic in a 1:1 mixture with femoral head allograft, with good results in 43 patients at a mean follow-up of two years. Both cemented and uncemented acetabular components were used, with no migration. However, radiolucent lines were observed at the component-graft interface in ten of 34 patients who had received an uncemented component, and one of nine patients with a cemented implant. ${ }^{73}$ Less satisfactory results have been reported using an A-W glass ceramic as a bone-graft substitute. ${ }^{74}$

The HHS was adopted as an outcome measure to enable comparison with other series. It has been shown to have 
good reliability and validity compared to other scores, although some domains, particularly the range of movement, have been reported to demonstrate ceiling effects. ${ }^{75}$ Only the patient-reported outcomes were obtained, which have been shown to provide excellent concordance with the surgeon-assessed $\mathrm{HHS}^{.76}$ In our series there was an improvement in both the pain and function portions of the HHS.

The radiological evaluation of graft incorporation was difficult to assess. Apapore 60 is more radiodense than bone graft and obscures any trabecular pattern that may be present. In addition, phase-pure HA undergoes reabsorption by giant cell reaction, a process that is very slow and may be incomplete. Due to the longer term presence of the $\mathrm{HA}$ in the graft, the usual method of assessing remodelling proposed by Conn et al, ${ }^{34}$ where remodelling is defined as isodensity of the graft and host bone, cannot be used. The best that can be shown is the gradual incorporation of the dense Apapore granules.

No patient required revision for clinical symptoms, and in the two in whom there was radiological evidence of acetabular migration, this occurred early and then stabilised. We suspect that it was a reflection of inadequate impaction of the graft at the time of surgery. A number of patients developed radiolucent lines, all of which occurred early and have not progressed. Their significance is unclear, and the patients remain under review.

There are a number of shortcomings in this study. At present the mean follow-up is limited to 60 months. Although the AAOS classification has been reported to have poor inter- and intra-observer reliability with plain radiographs, ${ }^{77}$ we used it to classify the bone defects both radiologically and intra-operatively. Nevertheless, no formal inter- or intra-observer evaluation of reliability was performed when assessing remodelling on the post-operative radiographs. We describe a heterogeneous series of complex primary and revision cases. We recognise that the biological environments of the two groups were different. Autogenous graft from the femoral head was not used in the complex primary acetabular reconstructions owing to concerns about the adequacy and quality of the graft prepared in a theatre setting and in four hips the femoral head after resection was considered too small to provide adequate graft.

Acetabular reconstruction in both primary and revision surgery using a 1:1 mixture by weight of frozen, ground irradiated bone and Apapore 60 appears to be a viable method for managing acetabular defects. This approach goes some way to addressing the problems of bone supply and disease transmission, as well as theoretically improving the mechanical properties of the impacted bed. The use of plain radiographs to assess incorporation remains difficult. Although the medium-term clinical results appear promising, longer follow-up will be required to establish whether this technique is as effective as using fresh-frozen allograft.
Our thanks go to Mrs V. Hamilton for all of her work updating the hip arthroplasty database and $\mathrm{Mr} \mathrm{A}$. August for allowing us to use his patients. I. McNamara gratefully acknowledges the financial support of the Furlong Research Charitable Foundation (FRCF). In addition, this work was supported in part by the National Institute for Health Research.

No benefits in any form have been received or will be received from a commercial party related directly or indirectly to the subject of this article.

\section{References}

1. Schreurs BW, Slooff TJ, Buma P, Gardeniers JW, Huiskes R. Acetabular reconstruction with impacted morsellised cancellous bone graft and cement: a 10- to 15year follow-up of 60 revision arthroplasties. J Bone Joint Surg [Br] 1998;80-B:391-5.

2. Schreurs BW, Zengerink M, Welten ML, van Kampen A, Slooff TJ. Bone impaction grafting and a cemented cup after acetabular fracture at 3-18 years. Clin Orthop 2005;437:145-51.

3. Simonds RJ, Holmberg SD, Hurwitz RL, et al. Transmission of human immunodeficiency virus type 1 from a seronegative organ and tissue donor. N Engl J Med 1992;326:726-32

4. Ireland L, Spelman D. Bacterial contamination of tissue allografts: experiences of the donor tissue bank of Victoria. Cell Tissue Bank 2005;6:181-9.

5. Schreurs BW, Keurentjes JC, Gardeniers JW, et al. Acetabular revision with impacted morsellised cancellous bone grafting and a cemented acetabular component: a 20- to 25-year follow-up. J Bone Joint Surg [Br] 2009;91-B:1148-53.

6. Ochs BG, Schmid U, Rieth J, et al. Acetabular bone reconstruction in revision arthroplasty: a comparison of freeze-dried, irradiated and chemically-treated allograft vitalised with autologous marrow versus frozen non-irradiated allograft. J Bone Joint Surg [Br] 2008;90-B:1164-71.

7. Buckley SC, Stockley I, Hamer AJ, Kerry RM. Irradiated allograft bone for acetabular revision surgery: results at a mean of five years. J Bone Joint Surg [Br] 2005;87-B:310-13.

8. Holt GM, Stockley I, Elson I, Ibbotson RA. A comparison of the performance of irradiated and non-irradiated bone graft in hip surgery. Hip Int 2001;11:18-24.

9. Bankes MJK, Allen PW, Aldam CH. Results of impaction grafting in revision hip arthroplasty at two to seven years using fresh and irradiated allograft bone. Hip Int 2003;13:1-11.

10. Emms NW, Buckley SC, Stockley I, Hamer AJ, Kerry RM. Mid- to long-term results of irradiated allograft in acetabular reconstruction: a follow-up report. J Bone Joint Surg [Br] 2009;91-B:1419-23.

11. Fosse L, Rønningen H, Benum P, Lydersen S, Sandven RB. Factors affecting stiffness properties in impacted morsellized bone used in revision hip surgery: an experimental in vitro study. J Biomed Mater Res A 2006;78:423-31.

12. Fosse L, Rønningen H, Lund-Larsen J, Benum P, Grande L. Impacted bone stiffness measured during construction of morsellised bone samples. J Biomech 2004;37:1757-66

13. Phillips A, Pankaj P, May F, et al. Constitutive models for impacted morsellised cortico-cancellous bone. Biomaterials 2006;27:2162-70.

14. Voor MJ, Nawab A, Malkani AL, UIlrich CR. Mechanical properties of compacted morselized cancellous bone graft using one-dimensional consolidation testing. J Biomech 2000;33:1683-8.

15. Voor MJ, White JE, Grieshaber JE, Malkani AL, Ullrich CR. Impacted morselized cancellous bone: mechanical effects of defatting and augmentation with fine hydroxyapatite particles. J Biomech 2004;37:1233-9

16. Keaveny TM, Hayes WC. A 20 -year perspective on the mechanical properties of trabecular bone. J Biomech Eng 1993;115:534-42.

17. Keaveny TM, Morgan EF, Niebur GL, Yeh OC. Biomechanics of trabecular bone Annu Rev Biomed Eng 2001;3:307-33.

18. Keaveny TM, Wachtel EF, Guo XE, Hayes WC. Mechanical behavior of damaged trabecular bone. J Biomech 1994;27:1309-18.

19. Keaveny TM, Wachtel EF, KopperdahI DL. Mechanical behavior of human trabecular bone after overloading. J Orthop Res 1999;17:346-53.

20. Grimm B, Miles AW, Turner IG. Optimizing a hydroxyapatite/tricalcium-phosphate ceramic as a bone graft extender for impaction grafting. J Mater Sci Mater Med 2001;12:929-34.

21. Aulakh TS, Jayasekera N, Kuiper JH, Richardson JB. Long-term clinical outcomes following the use of synthetic hydroxyapatite and bone graft in impaction in revision hip arthroplasty. Biomaterials 2009;30:1732-8.

22. Blom AW, Grimm B, Miles AW, Cunningham JL, Learmonth ID. Subsidence in impaction grafting: the effect of adding a ceramic bone graft extender to bone. Proc Inst Mech Eng H 2002;216:265-70.

23. Bolder SB, Verdonschot N, Schreurs BW, Buma P. The initial stability of cemented acetabular cups can be augmented by mixing morsellized bone grafts with tricalciumphosphate/hydroxyapatite particles in bone impaction grafting. J Arthroplasty 2003;18:1056-63 
24. Bolder SB, Verdonschot N, Schreurs BW, Buma P. Acetabular defect reconstruc tion with impacted morsellized bone grafts or TCP/HA particles: a study on the mechanical stability of cemented cups in an artificial acetabulum model. Biomaterials 2002;23:659-66.

25. Oonishi H, Iwaki Y, Kin $\mathbf{N}$, et al. Hydroxyapatite in revision of total hip replacements with massive acetabular defects: 4- to 10-year clinical results. J Bone Joint Surg [Br] 1997;79-B:87-92

26. Arts JJ, Gardeniers JW, Welten ML, et al. No negative effects of bone impaction grafting with bone and ceramic mixtures. Clin Orthop 2005;438:239-47.

27. Hing K. Bioceramic bone graft substitutes: influence of porosity and chemistry. Int J Appl Ceram Technol 2005;2:184-99.

28. Hing KA. Bone repair in the twenty-first century: biology, chemistry or engineering? Philos Trans A Math Phys Eng Sci 2004;362:2821-50.

29. Hing KA, Annaz B, Saeed S, Revell PA, Buckland T. Microporosity enhances bioactivity of synthetic bone graft substitutes. J Mater Sci Mater Med 2005;16:467-75.

30. Hing KA, Best SM, Tanner KE, Bonfield W, Revell PA. Mediation of bone ingrowth in porous hydroxyapatite bone graft substitutes. J Biomed Mater Res 2004;68:187-200

31. Eggli PS, Müller W, Schenk RK. Porous hydroxyapatite and tricalcium phosphate cylinders with two different pore size ranges implanted in the cancellous bone of rabbits: a comparative histomorphometric and histologic study of bony ingrowth and implant substitution. Clin Orthop 1988;232:127-38.

32. D'Antonio JA, Capello WN, Borden LS, et al. Classification and management of acetabular abnormalities in total hip arthroplasty. Clin Orthop 1989;243:126-37.

33. Harrris WH. Traumatic arthritis of the hip afer disloction and acetabular fractures treatment by mold arthroplasty. An end result study using a new method of result evaluation. J Bone Joint Surg [Am] 1969;51-A:737-55

34. Conn RA, Peterson LFA, Stauffer RN, Ilstrup D. Management of acetabular deficiency: long-term results of bone grafting the acetabulum in total hip arthroplasty. Orthop Trans 1985;9:451-52.

35. Gie GA, Linder L, Ling RS, et al. Impacted cancellous allografts and cement for revision total hip arthroplasty. J Bone Joint Surg [Br] 1993;75-B:14-21.

36. DeLee JG, Charnley J. Radiological demarcation of cemented sockets in total hip replacement. Clin Orthop 1976;121:20-32.

37. Murray DW, Carr AJ, Bulstrode C. Survival analysis of joint replacements. J Bone Joint Surg [Br] 1993;75-B:697-704.

38. Rothman KJ. Estimation of confidence limits for the cumulative probability of survival in life table analysis. J Chronic Dis 1978;31:557-60

39. Schreurs BW, Bolder SB, Gardeniers JW, et al. Acetabular revision with impacted morsellised cancellous bone grafting and a cemented cup: a 15- to 20-year follow-up. J Bone Joint Surg [Br] 2004;86-B:492-7.

40. Azuma T, Yasuda H, Okagaki K, Sakai K. Compressed allograft chips for acetabular reconstruction in revision hip arthroplasty. J Bone Joint Surg [Br] 1994;76-B:740-4.

41. Pitto RP, Di Muria GV, Hohmann D. Impaction grafting and acetabular reinforcement in revision hip replacement. Int Orthop 1998;22:161-4.

42. Winter E, Piert M, Volkmann R, et al. Alogeneic cancellous bone graft and a Burch-Schneider ring for acetabular reconstruction in revision hip arthroplasty. J Bone Joint Surg [Am] 2001;83-A:862-7.

43. Schreurs BW, Busch VJ, Welten ML, et al. Acetabular reconstruction with impaction bone-grafting and a cemented cup in patients younger than fifty years old. J Bone Joint Surg [Am] 2004;86-A:2385-92.

44. Edwards SA, Pandit HG, Grover ML, Clarke HJ. Impaction bone grafting in revision hip surgery. J Arthroplasty 2003;18:852-9.

45. Sanzén L, Carlsson A. Transmission of human T-cell lymphotrophic virus type 1 by a deep-frozen bone allograft. Acta Orthop Scand 1997;68:72-4.

46. Eastlund T, Strong DM. Infection disease transmissions through tissue transplantation. In: Phillips GO, Kearney JN, Strong DM, von Versen R, Nather A, eds. Advances in tissue banking. Vol. 7. Singapore: World Scientific, 2003:51-131.

47. Simonds RJ. HIV transmission by organ and tissue transplantation. AIDS 1993;7:35 8.

48. Pruss A, Kao M, Gohs U, et al. Effect of gamma irradiation on human cortical bone transplants contaminated with enveloped and non-enveloped viruses. Biologicals 2002;30:125-33.

49. Mehendale S, Learmonth ID, Smith EJ, et al. Use of irradiated bone graft for impaction grafting in acetabular revision surgery: a review of fifty consecutive cases. Hip Int 2009;19:114-19.

50. Currey JD, Foreman J, Laketic I, et al. Effects of ionizing radiation on the mechanical properties of human bone. J Orthop Res 1997;15:111-17.
51. Anderson MJ, Keyak JH, Skinner HB. Compressive mechanical properties of human cancellous bone after gamma irradiation. J Bone Joint Surg [Am] 1992;74A:747-52.

52. Moreau MF, Gallois Y, Baslé MF, Chappard D. Gamma irradiation of human bone allografts alters medullary lipids and releases toxic compounds for osteoblast-like cells. Biomaterials 2000;21:369-76.

53. Hassaballa M, Mehendale S, Poniatowski S, et al. Subsidence of the stem after impaction bone grafting for revision hip replacement using irradiated bone. J Bone Joint Surg [Br] 2009;91-B:37-43

54. Cornu 0, Bavadekar A, Godts B, et al. Impaction bone grafting with freeze-dried irradiated bone. Part II: changes in stiffness and compactness of morsellized grafts: experiments in cadavers. Acta Orthop Scand 2003;74:553-8.

55. Cornu 0, Bavadekar A, Godts N, et al. Impaction bone grafting with freeze-dried irradiated bone. Part I: femoral implant stability: cadaver experiments in a hip simulator. Acta Orthop Scand 2003;74:547-52.

56. Cornu $\mathbf{0}$, Libouton $\mathbf{X}$, Naets $\mathbf{B}$, et al. Freeze-dried irradiated bone brittleness improves compactness in an impaction bone grafting model. Acta Orthop Scand 2004;75:309-14.

57. Hamer AJ, Stockley I, Elson RA. Changes in allograft bone irradiated at different temperatures. J Bone Joint Surg [Br] 1999;19:342-4.

58. Godette GA, Kopta JA, Egle DM. Biomechanical effects of gamma irradiation on fresh frozen allografts in vivo. Orthopedics 1996;19:649-53.

59. Jinno T, Miric A, Feighan J, et al. The effects of processing and low dose irradiation on cortical bone grafts. Clin Orthop 2000;375:275-85.

60. Voggenreiter G, Ascherl R, Blümel G, Schmit-Neuerburg KP. Extracorporeal irradiation and incorporation of bone grafts: autogeneic cortical grafts studied in rats. Acta Orthop Scand 1996;67:583-8.

61. Dunlop DG, Brewster NT, Madabhushi SP, et al. Techniques to improve the shear strength of impacted bone graft: the effect of particle size and washing of the graft. $J$ Bone Joint Surg [Am] 2003;85-A:639-46.

62. Hannink G, Schreurs BW, Buma P. Irradiation has no effect on the incorporation of impacted morselized bone: a bone chamber study in goats. Acta Orthop 2007;78:31-8.

63. Slooff TJ, Huiskes R, van Horn J, Lemmens AJ. Bone grafting in total hip replacement for acetabular protrusion. Acta Orthop Scand 1984;55:593-6.

64. UIImark G. Bigger size abd defatting of bone chips will increase cup stability. Arch Orthop Trauma Surg 2000;120:445-7.

65. Bolder SB, Schreurs BW, Verdonschot N, et al. Particle size of bone graft and method of impaction affect initial stability of cemented cups: human cadaveric and synthetic pelvic specimen studies. Acta Orthop Scand 2003;74:652-7.

66. Bolder SB, Verdoschot N, Schreurs BW. Technical factors affecting cup stability in bone impaction grafting. Proc Inst Mech Eng H 2007;221:81-6.

67. Arts JJ, Verdonschot N, Buma P, Schreurs BW. Larger bone graft size and washing of bone grafts prior to impaction enhances the inital stability of cemented cups: experiments using a synthetic acetabular model. Acta Orthop 2006;77:227-33.

68. Craig RF. Craig's: soil mechanics. Seventh ed. London: Spon Press, 2004.

69. Arts JJ, Schreurs BW, Buma P, Verdonschot N. Cemented cup stability during lever-out testing after acetabular bone impaction grafting with bone graft substitutes mixed containing morselized cancellous bone and tricalcium phosphate: hydroxyapatite granules. Proc Inst Mech Eng H 2005;219:257-63.

70. Arts JJ, Walschot LH, Verdonschot N, Schreurs BW, Buma P. Biological activity of tricalciumphosphate/hydroxy-apatite granules mixed with impacted morsellized bone graft: a study in rabbits. J Biomed Mater Res B Appl Biomater 2007;81:476-85.

71. Blom AW, Cunningham JL, Hughes G, et al. The compatability of ceramic bone graft substitutes as allograft extenders for use in impaction grafting of the femur. $J$ Bone Joint Surg [Br] 2005;87-B:421-5

72. Sudo A, Hasegawa M, Fukuda A, et al. Acetabular reconstruction using a cementless cup and hydroxyapatite granules: 3- to 8-year clinical results. J Arthroplasty 2007;22:828-32

73. Blom AW, Wylde V, Livesey C, et al. Impaction bone grafting of the acetabulum at hip revision using a mix of bone chips and a biphasic porous ceramic bone graft substitute. Acta Orthop 2009;80:150-4.

74. Kawanabe $\mathbf{K}$, Lida $\mathbf{H}$, Matsusue $\mathbf{Y}$, et al. A-W glass ceramic as a bone substitute in cemented hip arthroplasty: 5 hips followed 2-10 years. Acta Orthop Scand 1998;69:237-42.

75. Söderman P, Malchau H. Is the Harris hip score system useful to study the outcome of total hip replacement? Clin Orthop 2001;384:189-97.

76. Mahomed NN, Arndt DC, McGrory BJ, Harris WH. The Harris hip score: comparison of patient self-report with surgeon assessment. J Arthroplasty 2001;16:575-80.

77. Gozzard C, Blom A, Taylor A, Smith E, Learmonth I. A comparison of the reliability and validity of bone stock loss classification systems used for revision hip surgery. $J$ Arthroplasty 2003;18:638-42. 